УДК 821.163.41-31.09 Албахари Д. https://doi.org/10.18485/godisnjak.2021.16.10

Јован Л. Гавриловић*

Универзитет у Београду

Филолошки факултет, доктранд
Оригинални научни рад

Примљен: 01. 09. 2021.

Прихваћен: 05. 11. 2021.

\title{
КАФКИЈАНСКИ ЕЛЕМЕНТИ У РОМАНИМА О ЕМИГРАЦИЈИ ДАВИДА АЛБАХАРИЈА
}

Рад се бави анализом романа Снежни човек Давида Албахарија, полазећи од теорије о Кафка машини Жила Делеза и Феликса Гатарија. Строго уређену и свепрожимајућу конструкцију, коју Делез и Гатари примећују у већини Кафкиних дела, а која сачињава машину из које Кафкини јунаци не могу да побегну, могуће је пронаћи у Албахаријевом роману, понајвише у нараторовом доживљавању напуштене домовине и у његовој немогућности да се одупре искуству стеченом у њој. Напуштена територија сагледава се као репресиван простор који у себи заробљава наратора чак и у случају његовог одласка на други континент, што кореспондира са мотивима из Кафкиних дела, где замршени системи (попут закона у Процесу) и апсурдни догађаји (попут претварања у инсекта у Преображсају) на сличан начин темељно прожимају стварност главних јунака.

Кључне речи: кафкијанско, машина, емиграција, територија, детеритоијализација, историографија.

\section{Кафка машина}

У својој студији о делу (и лику) Франца Кафке, Жил Делез и Феликс Гатари настоје да пронађу једну једину инстанцу на коју се може свести готово комплетан опус овог писца. Проучавајући не само Кафкине прозне радове, већ и његова писма, па чак и цртеже које је лично правио, Делез и Гатари усвајају термин „Кафка машина”, који потом успешно изналазе у

*gavrilovicjovan0@gmail.com 
низу Кафкиних радова. Према њима: „Кафка машину конституишу садржаји и изрази формализовани до одређених степени од стране неформалних материјала који у њу улазе, и излазе пролазећи кроз сва могућа стања. Ући у машину или изаћи из ње, бити у машини, ходати око ње, прилазити јој - ово су све и даље компоненте саме машине.” (Делез, Гатари 1986: 7). Кафка машина налази се у сржи структуре најважнијих дела која сачињавају Кафкин опус, и, према Делезу и Гатарију, многа од њих се могу тумачити управо на основу проналаска и истицања момената у којима се Кафка машина користи у наративу: „Овај опус је ризом, један брлог. Замак има више улаза чија правила коришћења и чије локације нису веома добро познати. Хотел у Америци има безброј главних врата и споредних врата која надгледа безброј стражара; чак има улазе и излазе без врата." (Делез, Гатари 1986: 3). Машину унутар Кафкиних радова најлакше је, наравно, приметити у приповеткама попут „У кажњеничкој колонији”, у којима значајна улога припада дословним механичким конструкцијама, али Делез и Гатари изналазе феномен Кафка машине чак и у Кафкином вероватно најпознатијем делу: „У Процесу, поново се ради о одређеној машини као што је сингуларна машина правде; али њено јединство је толико небулозно, машина утицаја, контаминација, да више нема разлике између пребивања унутра или споља.” (Делез, Гатари 1986: 8).

Кафка машина, дакле, представља конструкцију, један систем, који, био он за ликове опипљив или не, прожима свет у којем се они налазе и у том прожимању сеже у готово сваки кутак тог света. Ипак, премда су Делез и Гатари тврдили да унутар машине долази до брисања дистинкције између боравка у њој или ван ње, код Кафке је улазак у машину увек догађај сам по себи, и он се без знатних потешкоћа може пронаћи, будући да се углавном налази на почетку дела, и то понекад већ у првим реченицама: „Када се Грегор Самса једног јутра пробудио након немирних снова, примијетио је да се у кревету био претворио у големог кукца” (Кафка 1977: 63), или: „Јозефа К. мора да је нетко оклеветао, јер је једног јутра био ухапшен иако ништа није скривио." (Кафка 1977: 7). Нашавши се у процесу сопственог преображаја, Грегор Самса се самим тим нашао заробљен унутар кафкијанске машине, док се, на идентичан начин, чином хапшења, Јозеф К. исто тако заробљава унутар исте онакве машине. Ипак, Кафкина дела, што се види из цитираних почетних исказа, почињу in medias res, односно јунак је већ у машини, и ретко када бива речи о ономе што је заробљавању у машини претходило, што, наравно, не значи да једно пре уопште није постојало. О том пре пак заиста нема много детаља у Кафкиним делима. 
Делез и Гатари, у цитираној студији, мањак информација о стању јунака Кафкиних дела које претходи уласку у Кафка машину објашњавају феноменом детериторијализације, који са пишчевог стварног живота ${ }^{1}$ преносе у његова дела. „Мањинска књижевност не потиче од мањинског језика; у питању је пре оно што мањина производи унутар граница језика већине. Али прва карактеристика мањинске књижевности у сваком случају јесте да у њој језик бива стављен под утицај високог коефицијента детериторијализације.” (Делез, Гатари 1986: 16). Будући родом Чех али се истовремено налазећи у токовима немачке књижевности, Кафка је, за Делеза и Гатарија, детериторијализован из сопственог националног локуса и измештен у далеко крупнију немачку књижевну заједницу, у којој писци попут њега, макар се служили језиком већине, увек имају културно мањински статус. Делез и Гатари оцениће овакав процес Кафкине стварне детериторијализације у културни образац већине као катализатор за детериторијализацију до које долази у његовим делима, те се тако преображај Грегора Самсе објашњава баш на тај начин: „... процес Грегорове детериторијализације кроз његов постанак животињом...” (Делез, Гатари 1986: 14), што, на нивоу текста приповетке, нема никакве везе са националном територијализацијом. Исто тако, Јозеф К. је, путем хапшења, детериторијализован из свог претходног живота и измештен у специфичан правосудни систем који сачињава обзоре кафкијанске машине тог романа. Још један пример: у приповеци „Извештај за једну академију”, мајмун Црвени Петер подноси извештај о томе како је научио да се понаша као људско биће, што Делез и Гатари објашњавају на следећи начин: „... животиња заробљена од стране човека бива детериторијализована путем људске силе..." (Делез, Гатари 1986: 14), а будући да је на почетку приповетке ухваћен и одведен из своје родне Африке, мајмун чином заробљавања и измештања из домовине бива подвргнут процесу детериторијализације.

Уопштено схваћена, структура већине Кафкиних дела, према Делезу и Гатарију, састоји се из две наведене компоненте: процеса детериторијализације и Кафка машине. Однос ових компоненти јесте комплементаран: моменат детериторијализације истовремено је и моменат уласка у машину, и управо је то оно кафкијанско што настојимо да пронађемо у делима Давида Албахарија.

${ }^{1}$ Позитивистички моменти Делезове и Гатаријеве студије највероватније дугују своје присуство чињеници да се потоњи бавио психоналаизом, што је случај и са бројним (за овај рад неважним) анализама Кафкине личности путем едиповских мотива. 


\section{Снежни човек: Заснивање Албахари машине}

Низ романа насталих у годинама након Албахаријевог пресељења у Канаду 1994. године били су писани са истом почетном ситуацијом одлазак из земље рођења и долазак у страну, непознату земљу. Очигледно настали под утицајем пишчевог животног искуства, тих неколико романа - који, по реду објављивања, носе имена Снежни човек (1995), Мамаи, (1996) и Светски путник (2001) - баве се тематиком емиграције (самим тим и имиграције) на готово истоветан начин, и управо је захваљујући Албахаријевој доследности у приступу миграционој тематици могуће истаћи кафкијанску линију која се провлачи кроз сва три романа, и која готово на исти начин бива поновљена у нешто каснијем делу, Животињском изарству (2014), готово две деценије након објављивања првог наведеног романа.

Албахари одмах на почетку сваког од ова четири романа прави два избора који пресудно утичу на структуру сваке од три засебне приче, и та два избора чине поетичку основу која бива полазном тачком за истоветан развитак три релативно различите романескне нити. Та два избора су (1) бављење тематиком емиграције/имиграције и (2) бављење тематиком историографије. Прва тематика самом својом природом одређује оквире радњи свих наведених романа: неминовно се намеће једно овде и једно тамо, односно, конкретно говорећи, ликови делају под окриљем поларности Србије (овде) и Канаде (тамо), и та измештеност кључна је како за разумевање Албахаријеве поетике у овим делима тако и за сагледавање оног кафкијанског које се назире у тој поларности. Други Албахаријев избор - фокусираност на оно историјско - исто као и претходни избор формира линију са чије обе стране ликови делају у оквиру три романа, и који ће у структури ових дела јасно указати на једно сада и на једно $m a d a$, односно на садашњи тренутак (ратових деведесетих година) и на прошлост, која се може односити и на ближу историју (Други светски рат) и на ону даљу (време колонизације Америке или доба Римског царства). Албахаријеви романи са тематиком емиграције изграђени су, дакле, на пресеку те две поларности, односно на пресеку четири крајности које оне подразумевају. Ликови се крећу и фабуле се развијају на разини просторног контраста овде-сада и временског контраста сада-тада. Ипак, премда полазиште ових романа јесте могуће одредити тако „црно-бело”, и премда јесте једноставно рећи да, на пример, наратор Снежног човека одлази из Србије у Канаду и да се, на пример, наратор Мамиа непрестано креће између ратова деведесетих у својој садашњости и Другог светског рата у садашњости његове мајке, начин на који Албахари приступа спле- 
ту ових контраста ни у ком случају не може се описати на „црно-бели” начин. Који је разлог томе?

Албахарију је, наравно, изузетно стало до супротности коју измештање из човекове домовине значи по структуру његових романа, исто као што му је, наравно, стало до сагледавања и релативизовања историје и историографије из позиције човека постмодерног доба, но ни у ком случају Албахари није спреман да та два контраста остави на њиховим почетним местима. Ти контрасти нису успостављени са циљем да се снажно изрази промена коју они својом природом подразумевају. Потенцијални културолошки шок који може бити резултат одласка из Европе у Северну Америку и било какве промене настале једноставним протоком времена свакако могу бити захвални за одређену врсту романескне обраде, но Албахари чини управо супротно. Контраст је успостављен већ на почетку романа - наратор Снежног човека слеће на аеродром у Канади, Даниел Атијас долази у Банф у Светском путнику, наратор Мамиа већ на првим страницама обзнањује свој статус емигранта - и већ је тада јасно да сва три лика делају на разини једног овде, које се мора супротставити једном тамо, но, уместо да се фокусира управо на то супротстављање, Албахари га, напротив, сасвим намерно подрива. Временски и месни контраст бивају успостављени да би, како се фабула развија, били најпре релативизовани, а потом, и то углавном пре завршетка радње, сасвим разрушени.

У Снежном човеку реч је о српском писцу измештеном из своје земље у Канаду, у негативно окарактерисани академски миље, међу ликове који су готово сви до једног обезличени, означени искључиво заједничким именицама - шофер, жена, декан, професор, студент... Пресељење из Србије у Канаду обележава наратора у сваком тренутку његовог „новог живота” до те мере да он не успева да се разабере у новој средини, која за њега представља исључиво негативни ентитет. Знатан део романа посвећен је историографским рефлексијама у којима се назире идентична одбојност коју наратор изражава према академском свету и институцији образовања уопште. Немогућност прилагођавања новој средини као и неспособност занемаривања средине из које је наратор измештен на крају романа доводи до фигуративног али и дословног нестанка.

Контраст између овде и тамо истакнут је одмах на почетку Снежног човека. Приликом доласка на канађански аеродром, наратор романа на неколико места размишља да је отишао „у свет”. Чин одласка се, дакле, конкретизује путем проширавања: уместо да о одласку размишља као о „одласку у Канаду”, где, наравно, заиста и одлази, наратор се одлучује за неодређени али исто толико уопштени термин „свет”. Овај одабир једног 
термина уместо другог подразумева два става. Прво, место на које се долази схвата се генерализовано; рекавши да одлази „у свет”, наратор је исто тако могао да оде у било коју другу државу поред Канаде а да исказ и даље буде тачан, и то управо због своје неодређености. Место на које се долази, дакле, није битно тачно одредити. Други став који одабир термина „свет” као одредницу одласка подразумева јесте следећи: уколико се чином одласка одлази „у свет”, и ако је све што се налази изван првобитног места схваћено као „свет”, онда место из којег се одлази не може да буде део тог „света”. С једне стране, дакле, Србија деведесетих година, која у моменту одласка „у свет” постаје носилац одреднице тамо, бива конкретно портретисана како се радња романа одвија, док се, с друге стране, место на које се долази, односно Канада, која постаје носилац одреднице овде, никада не приближава читаоцу ни на који начин. Отуд, уосталом, ниједан од споредних ликова никада не бива именован властитом именицом, већ увек заједничком: шофер је шофер, професор политичких наука је професор политичких наука, декан је декан итд. Заправо, једина два имена која се спомињу јесу Кафкино, што је крајње индикативно по питању тематике овог рада, као и име Фреди, које наратор даје свим псима које види, и о чему ће бити речи даље у раду.

Који је онда значај супротстављања Србије и света? Јасно је да се одабир термина „свет” може повезати са одласком у непознато, што једним делом и јесте случај. Могло би се, у том погледу, рећи да наратор проживљава неку врсту културолошког шока по приспећу на аеродром и приликом вожње са шофером, јер се он на једном месту осећа „као да улазим у лавиринт из којег ћу касније морати с напором да излазим" (Албахари 2015: 159). Свет из којег је Србија (односно место из којег се одлази) апстрахована показује се као непознат и конфузан. Канађанске улице у наратору буде осећај заробљености у лавиринту, што по њега затим има дезоријентирајуће дејство. На површини, наравно, може бити речи о новом месту које је по сопственој природи непознато оном ко се на њему по први пут нађе. Ипак, одабравши да опише Канаду као „лавиринтску", и претходно означивши исту ту државу као део широког термина „света”, јасно је да се Албахари определио за употребу синегдохе, у оквиру које се Канада схвата као само један део „света”, који ипак мора бити репрезентативан део тог света. Канада је конфузна и лавиринтска, дакле и читав „свет” мора бити такав. Ова нараторова склоност према уопштавању већ је запажена: „Мржња према једном професору обухвата и универзитет...” (Куниш 2005: 115). Оно што Канаду, па самим тим и „свет” чини таквим у нараторим очима произилази из чина одласка. На 
делу је, наравно, детериторијализација о којој Делез и Гатари говоре. Чин одласка из претходне земље, у овом случају Србије, везан је за конкретно именован и у току романа историјски конкретизован простор, док је чин доласка стопљен са остатком света изван Србије и на тај начин везан за именовану, премда никад конкретизовану, Канаду. У оквирима детериторијализације, и то онакве каква се манифестује у Албахаријевим романима, никада није фокус на месту на које се долази, већ, баш напротив, пажња се посвећује искључиво месту са којег се одлази. Зато је, када је реч о Албахаријевим избегличким романима, адекватније користити термин „емиграција” уместо „имиграција”. Наравно, јасно је да до оба чина мора доћи, што се и дешава, али чин емигрирања, односно одласка, семантички је амплификован управо конкретизацијом која се придаје нараторовој домовини, док чин имигрирања, премда испуњен нараторовим доласком у Канаду, никада се не посматра као такав, то јест као са̂м чин имигрирања, већ увек и искључиво као једноставан продужетак емиграције. Зато се Канада схвата као један од многих делова готово апстрактног „света”, док је нараторова домовина непрестано у фокусу његових рефлексија и разговора које води с другим ликовима; није важно где се долази, важно је одакле се одлази.

Турбулентни историјски тренуци, који су у оквиру радње Снежног човека сувремени главном јунаку, премда хиљадама километара удаљени, и даље „владају” његовим бићем. Иста је ситуација и у случају Мамияа и Светског путника - детериторијализација акцентује територију која се напушта, док се о новој територији готово и не размишља. До овога долази управо због поменутих историјских тренутака; трауматично искуство ратова деведесетих година обележава два неименована наратора и Даниела Атијаса, и управо је због тога акценат на напуштеној територији - због онога што ликови са те територије носе са собом и чега не могу да се ослободе.

Да је измештени човек попут наратора Снежног човека неспособан да заиста изађе испод окриља сопствене домовине показује се најпре посредно, путем мотива сока од поморанџе, који се јавља неколико пута у роману, и увек на местима када се долази у нову средину - најпре по доласку у кућу у којој ће наратор боравити, потом у канцеларији приликом његовог првог одласка на кампус канађанског универзитета. Сваки пут када је присутан мотив сока истовремено траје трвење између оног овде и оног тамо. Нашавши се у новим и непознатим срединама, наратор одмах размишља о соку од поморанџе, и то с таквим интензитетом да не би било нетачно ту потребу назвати патолошком: „Један од показатеља немира који 
га прожима јесте и та скоро патолошка потреба за соком од поморанџе.” (Чарни 2005: 113). Ипак, тек касније у роману постаје јасно који је значај овог мотива, и то у тренутку када наратор мисли: „Да није било сока од поморанџе, одавно бих био код куће...” (Албахари 2015: 180). „Кућа” о којој се ради не представља ону која је наратору стављена на располагање у Канади, већ његову домовину. Сок од поморанџе, сагледан кроз нараторову визуру, доводи се у блиску везу са напуштеном територијом, и премда он, наравно, будући обичан сок, не може представљати њену замену, јасно је да појавом овог мотива долази до одређене врсте компромиса који наратор изналази у сопственој детериторијализацији. Овакво стање ствари, у којем један једини мотив, у виду обичног предмета, успева да ублажи дејства детериторијализације у Снежном човеку кореспондира са истим случајем који Делез и Гатари запажају у Кафкином „Преображају”: „Рекли бисмо да се процес Грегорове детериторијализације кроз његово постајање животињом на тренутак зауставља... Да би га задовољила, његова сестра желела је да испразни целу собу. Али Грегор је одбио да пусти портрет даме у крзну. Држи се портрета као последње територијализоване слике.” (Делез, Гатари 1986: 14-15). Исти је случај и са соком од поморанџе. Одређена својства која су приписана напуштеној територији, а која никад нису именована, припојена су најобичнијем предмету на начин који такође никад није разјашњен. Привремено смирење које наратор осећа у контакту са соком од поморанџе лишено је рационализације, што га неминовно измешта у просторе нагонског, али и патолошког, у чијим границама можда баш и лежи иронијски аспект овог мотива. „Последња територијализована слика", како Делез и Гатари називају овакав мотив, од самог почетка одређена је као неуспела слика: Грегор ће се свеједно претворити у бубу, а наратор Снежног човека има сопствену врсту трансформације у завршници романа. Трење које настаје између два света - у случају „Преображаја” света људи и света инсеката, у случају Снежног човека света једног овде и света једног тамо - то трење настоји да буде ублажено посредством мотива који су до те мере банални да је потреба два лика за таквим предметима онолико комична колико трагична - комична због баналности, трагична због неуспеха тих територијализованих слика.

Јасно је, дакле, да се територијализација над новом средином не може успоставити ни на који начин. Баналност сока од поморанџе и свеопшта повученост и збуњеност наратора о томе сведоче сасвим довољно. Ипак, док је до територијализације непознатог места немогуће доћи, поставља се питање разлога те немогућности, односно не успева ли територијализација због новог и непознатог, потенцијално хостилног окружења, или 
пак разлози за њену немогућност леже на сасвим супротном месту, то јест на територији која је напуштена. На крају крајева, жеља за територијализацијом обузима сваког Албахаријевог јунака у овим романима, што је случај и кад је реч о Кафкиним делима: „... у свим случајевима, ликови имају заједничку жудњу... за отпором детериторијализацији, и за ретериторијализацијом" (Полан 1986: xxv).

Истакли смо већ да није битно место на које се долази, већ оно које се напушта. Другим речима, територијализација је везана искључиво за нараторову домовину, и њеним напуштањем је више него јасно да до истог типа територијализације не може доћи на сасвим другој територији, ма где се она налазила у „свету”. Самим тим, наратор не успева да постигне нову територијализацију, не због немогућности сопственог територијализовања на простору једног новог овде, већ због последица детериторијализације настале одласком са простора одређеног као тамо. Одлазак са првобитне територије настаје као потреба за сопственим очувањем, те је у складу с тиме свако нараторово размишљање о том одласку увек представљено интензивним, на моменте чак трауматичним тоном: „Дошао сам зато што сам престао да трајем, био сам низ испрекиданих секвенци, увек почетак, никада крај...” (Албахари 2015: 163), и затим, срочено изузетно директно: „Превалио сам толики пут, помислио сам, да бих свој живот свео на оно од чега сам хтео да побегнем.” (Албахари 2015: 205). Управо овде наступа моменат расветљавања нараторове ситуације. Не ради се о одласку или о доласку, већ о бегу. Трауматично искуство ратова на Балкану деведестих година углавном фигурира у роману приликом разговора са професором политичких наука или другим људима из наратору толико омраженог света академије, но постоји један моменат у којем се ратови деведесетих година појављују у нараторовим рефлексијама саме од себе, а не као повод за разговор, који би у сваком случају увек био означен као површан. Тај моменат наступа приликом нараторовог силаска у подрум куће у којој борави: „Мисао о силаску подсетила ме је на подрум. Мисао о подруму подсетила ме је на прве приче о ваздушним нападима, о људима који су пуцали по парковима, клечећи иза клупа и украсног шибља.” (Албахари 2015: 189). Асоцијација на напуштену територију јавља се захваљујући територији подрума, која фигурира као просторна стимулација. Да ли сама скученост тог простора буди сећања на склоништа или нешто слично никад није прецизирано, али паралелизам који наратор изналази у слици подрума и слици Србије из које бежи конкретизује се својим преласком на просторе контрастирања Србије и „света” које је установљено још на самом почетку романа: „Дошао сам у свет, помислио сам, а ево ме где 
чучим у подруму попут одбачене лутке.” (Албахари 2015: 192). Подрум, дакле, контрастира са „светом” на исти начин на који Србија то чини у нараторовој свести. С обзиром на то да тај подрум изазива слике „људи који пуцају по парковима", јасно је да долази до продукције још једне територијализоване слике, али оне која је по свему различита од слике сока од поморанџе. Говорећи дословно, поставља се питање како подрум може постати територијализовани простор ако се он уопште не налази на месту које је за наратора територијализовано. Одговор лежи у већ наведеном цитату: „Превалио сам толики пут, помислио сам, да бих свој живот свео на оно од чега сам хтео да побегнем."

Нараторово суочавање са сликама ратова деведестих година, односно његов сусрет са управо оним од чега жели да побегне, сведочи о томе да до правог, истинског бега никад није ни дошло. Зато он на једном месту и размишља: „,.. тамо где сам очекивао да ћу наћи даљину, нисам је пронашао. Нисам бар пронашао 'даљину' која се открива приближавањем, јер без обзира на то колико сам путовао, нисам имао осећај да сам се приближио.” (Албахари 2015: 197). Важно је истаћи да се у нараторовој свести одлазак са првобитне територије повезује са идејом „бекства”, а никако са идејом „слободе”, што он и са̂м каже: „Потом сам 'даљину' почео да замишљам као 'бекство', а пошто сам о 'бекству' увек мислио као о 'уточишту', 'даљина' се претворила у неку врсту 'уточишта'." (Албахари 2015: 196-197). На овом месту се назире принципијелни квалитет који Делез и Гатари приписују Кафка машини - бекство је једина опција у свести заробљеника, а никако слобода, и премда се до бекства ни у ком случају не може доћи, линија могућег бега никада не дозвољава могућност свог преображаја у мисао о слободи (Делез, Гатари 1986: 2). Зато је наратор Снежног човека свестан да је „прешао из једног простора у други, а ништа се није изменило" (Албахари 2015: 198), као што је свестан тога да је „превалио толики пут да би свој живот свео на оно од чега је хтео да побегне".

Ово је главна кафкијанска нит провучена кроз сва три романа у центру овог рада. Простор Балкана током деведесетих година представљен је као оно што Делез и Гатари називају Кафка машином, и заробљеници тог простора - двојица наратора и Даниел Атијас - на уму једино имају могућност бекства са тог простора, која никада не бива испуњена. Због овога је контраст између овде и тамо који смо на почетку навели по својој природи непостојећи - никакво овде не може бити битно све док се унутар појединца и даље одвија оно што се у њему одвијало док је био на простору оног тамо. Зато је Канада означена као један део генерализованог „света”, 
док је Србија деведесетих година сасвим конкретизована. Поново, није битно где се долази, већ одакле се одлази. У томе и јесте разлика између поимања могућности слободе и могућност бега у свести Албахаријевих јунака. Појам слободе подразумева не само прекид првобитног стања, већ он у својој сржи носи јасно одређену слику стања ка којем се тежи. С друге стране, бег је омеђен просторима искључиво онога од чега се настоји да се побегне, те атрибути онога према чему се бежи никада не могу да надмаше атрибуте онога од чега се бежи. Према Делезу и Гатарију: „Проблем не лежи у томе да се буде слободан, већ у проналажењу начина изласка...” (Делез, Гатари 1986: 7-8). Управо због овога, на пример, Грегор Самса ни у једном тренутку не размишља о томе како да поново постане човек, већ концентрише све своје напоре на слепо, животињско делање унутар граница машине у којој је заробљен. Зато место на које се бежи не може ни бити битно у Албахаријевим романима: мора се побећи негде, све док се удаљава од онога тамо, но, како наратор Снежног човека и са̂м каже, „тамо где сам очекивао да ћу пронаћи 'даљину', нисам је пронашао". А зашто даљина не може да се нађе? Зато што је линија бекства сама по себи део Кафка машине: „Линија бекства је део машине.” (Делез, Гатари 1986: 8).

Немогућност успостављања истинске дискрепанције између нове територије и оне која се напушта лежи управо у кафкијанским квалитетима приписаним овој потоњој. Пратећи излагање Делеза и Гатарија, постаје очигледна чињеница да је чин путовања у Канаду које наратор Снежног човека предузима саставни део Кафка (тј. Албахари) машине из које он жели да побегне. И даље се налазећи под утицајем онога што је хиљадама километара удаљено у простору, наратор романа показује немогућност изласка из машине, што га ставља у позицију готово идентичну Грегору Самси, који не може да заустави процес преображаја, или Јозефу К, чије разабирање унутар законске машине Проиеса од самог почетка бива онемогућено.

Једно поглавље Кафкиног Процеса на сасвим адекватан начин подвлачи немогућност успостављања поменутог јаза између овде и тамо. Реч је о петом поглављу, насловљеном „Батинаш” (у оригиналу „Der Prügler"), у којем Јозеф К. у просторијама банке у којој је запослен наилази на епонимног батинаша, који шибом удара двојицу стражара из првог поглавља. Да би зачудни ефекат био још јачи, идућег дана, отворивши врата исте те просторије, Јозеф К. наилази на идентичну сцену, и то настављену баш оданде где ју је претходног дана прекинуо, као да се ради о заустављеном и поново пуштеном снимку. Просторије у којима се одвија 
Јозефов процес претходно су јасно дефинисане - ради се о поткровљу једне старе зграде у сиромашној четврти града, и у оквирима просторног домена покренутог процеса, то поткровље постаје појам комлементаран оном Албахаријевом тамо. Самим тим, Јозефова банка, која представља познато подручје наспрам збуњујућег и сасвим апсурдног подручја процеса, постаје еквивалентна Албахаријевом овде. Као и у јазу између две државе у Снежном човеку, и у овом случају је контраст две територије наизглед јасно успостављен. Али шта онда значи Јозефово налетање на батинаша и двојицу стражара? Није ли упливом оног тамо у оно овде у потпуности неутрализована могућност разабирања између два наизглед сасвим супротна ентитета? Свакако да јесте, јер успостављени контраст показује се као обичан привид. Закорачивши унутар граница машине, Јозеф К. преплиће сопствени живот с њом, и све оно што се дотад њему могло чини познатим постаје само по себи део те машине: „Ући у машину или изаћи из ње, бити у машини, ходати око ње, приближити јој се - све су ово и даље компоненте саме машине...” (Делез, Гатари 1986: 8).

Кафкијански обзори Снежног човека исте су природе као и свет закона у Процесу. Батинаш и стражари пратиће Јозефа К. без обзира на простор којим се он креће, јер је самим Јозефовим, тј. нараторовим кретањем унутар граница тог простора тај простор постао део процеса, односно део машине. Исто тако, ма где се нашао „у свету”, наратор Снежног човека наићи ће управо на оно од чега је, како саิм каже, желео да побегне, баш зато што се, попут Јозефа К, налази унутар машине из које је немогуће изаћи. На овај начин се разара контраст између овде и тамо.

Идентична је ситуација са Албахаријевим приступом историографији, односно у случају контраста између сада и тада. У Снежном човеку, ратови деведесетих година на Балкану супротстављени су историјској димензији тих простора, уобличеним у Историјском атласу средње $u$ источне Европе, који професор политичких наука поклања наратору. Поклањање тог атласа професор политичких наука пропратиће речима: „’'Ако су моје рачунице тачне', рекао је, 'ниједна граница није овде трајала педесет година, не рачунајући оне које су наметнуте природним препрекама."' (Албахари 2015: 194). Наравно, све паралеле са ситуацијом сувременом наратору и професору политичких наука сасвим су очигледне. Распад Југославије током деведесетих година двадесетог века, који формира једно сада, временски је супротстављен распарчавању и честом мењању граница држава источне Европе у атласу који нимало случајно није баш историјски, и које својом временском удаљеношћу формира једно тада. Ипак, премда се између сада и тада формира јаз у трајању од више веко- 
ва, супротности између ова два поларитета остају искључиво временске природе. Направивши паралелизам између тог сада и тог тада у Снежном човеку, Албахари је постигао ефекат идентичан укидању контраста између овде и тамо. Разлози том укидању исти су као и у претходном случају: простор Балкана се у свести наратора јасно одређује као простор једне Кафка машине. Исто као што место ни на који начин није битно за питање учинка те машине, тако је и историјски тренутак подједнако неважан када се ради о догађајима који конституишу унутрашњост машине. Будући саставни део Кафка - односно Албахари - машине, наратор Снежног човека ће и са̂м исказати нерелевантност времена по питању читаве своје ситуације: „Дошао сам зато што сам престао да трајем (наш курзив), био сам низ испрекиданих секвенци, увек почетак, никада крај...” (Албахари 2015: 163).

\section{Закључак}

Феномен Кафка машине чврсто је ужљебљен у структуру Албахаријевих романа који се баве тематиком емиграције. Специфична ситуација у којој се наратори налазе, која подразумева растрзаност између напуштене територије и оне на коју се дошло, служи као катализатор за кафкијанске елементе којима се описује нараторова немогућност истинског напуштања домовине. Кафка машина назире се управо у тој домовини, односно територији која је напуштена: чак и хиљадама километара удаљен од ње, наратор се и даље налази под њеним утиском, што суштински одређује његово биће на новој територији, тј. Канади, која служи као пуки рефлектор кафкијанске ситуације у коју је наратор смештен. Слепа потреба за бегом, коју Делез и Гатари приписују заробљеним ликовима у Кафкином опусу, одређује и Албахаријеве ликове, и то тако што се наратор Снежног човека готово сасвим дефинише на основу сопствене потребе за бекством од свега онога што његова домовина, тј. Балкан деведесетих година двадесетог века, подразумева. Албахари преузима оно суштинско у Кафкиним делима и смешта у сопствена, користећи се свим оним поступцима којима се користи и Кафка, али их увек реконтекстуализујући путем сопствене поетике и на тај начин градећи сопствену кафијанску слику стварности. 


\section{ЛИТЕРАТУРА}

Албахари 2015: Албахари, Давид. Снежни човек. Београд: Чаробна књига.

Deleuze, Guattari (Делез, Гатари) 1986: Deleuze, Gilles, Guattari, Felix. Kafka: Toward a Minor Literature. Minneapolis, London: University of Minnesota Press.

Kafka 1977: Kafka, Franc. Pripovijetke. Knjiga prva. Zagreb: Zora-GZH.

Kafka 1977: Kafka, Franc. Proces. Zagreb: Zora-GZH.

Куниш 2005: Куниш, Ханс Петер. „Спорије од истине”. Бранко Кукић (ур.). Часопис Градаи: часопис за књижевност, уметност и кулmуру. 31/156. Чачак: Дом културе Чачак, Уметничко друштво Градац, стр. 114-116.

Polan 1986: Polan, Dana. "Translator's Introduction" y: Deleuze, Guattari 1986: Deleuze, Gilles, Guattari, Felix. Kafka: Toward a Minor Literature. Minneapolis, London: University of Minnesota Press, стр. xxii-хxviii.

Чарни 2005: Чарни, Норберт. „Овде ћу остарити”. Бранко Кукић (ур.). Часопис Градаи: часопис за књижевност, уметност и културу. 31/156. Чачак: Дом културе Чачак, Уметничко друштво Градац, стр. 112-114.

Jovan L. Gavrilović

\section{KAFKAESQUE ELEMENTS IN DAVID ALBAHARI'S NOVELS ABOUT EMIGRATION}

\section{Summary}

Gilles Deleuze and Félix Guattari stipulate that Kafka's major works, be it novels or short stories, all share an identical entity envisioned as a concrete construction, both physical and psychological, that has the goal of encasing the story's protagonist inside a machine-like prison comprised of often illogical sequences that follow its own, to the protagonist wholly unfathomable rules. Thus, the machine can be found in the impenetrable judicial system of The Trial or the identically alienating walls of the title structure in The Castle, but it can also form the structural center of stories such as The Metamorphosis, where, in the absence of a literal machinic construction, a Kafka machine takes the form of the absurd change into which the protagonist is placed at the beginning of the text. This same type of structure - this machine - can also be found in Albahari's novels dealing with the act of emigrating from one's homeland and immigrating to a new territory, in a way that portrays the protagonist's homeland as the machine, with the new territory merely highlighting the insincere nature of the act of immigrating and the inability of the character 
to earnestly remove himself from his original territory. One of the defining characteristics of a Kafka machine is the absence of a route to freedom and a blind wish to escape the machine, which are both present in the consciousness of the narrator during his failed attempts at acclimatizing to a new territory. Unable to mentally remove himself from his own history and that of his nation, the narrator of Snow Man finds himself inprisoned in the same type of machine that Deleuze and Guattari find in Kafka's work.

Key words: Kafkaesque, machine, emigration, territory, deterritorialization, historiography. 